\title{
FUNGSI UPACARA PERTANIAN PADA MASYARAKAT GURADOG KABUPATEN LEBAK
}

\author{
Oleh Ria Intani T. \\ Balai Pelestarian Sejarah dan Nilai Tradisional Bandung \\ Jln. Cinambo No. 136 Ujungberung Bandung \\ Email: ria_intani@yahoo.com
}

\begin{abstract}
Abstrak
Mayoritas masyarakat Guradog adalah petani. Sehari-hari mereka teguh menjalankan tradisi warisan leluhurnya, antara lain melaksanakan upacara pertanian. Tujuan dari upacara tidak lain memohonkan keselamatan dalam kegiatan bertani, mulai dari kegiatan bertanam hingga panen.
\end{abstract}

Kata Kunci: petani, upacara.

\begin{abstract}
The major part of Guradog society are farmer. They keep doing their ancestors inheritance tradition daily. For example in implementing the agriculture ceremony. The purpose of this ceremony is supplicating safety in farming activity, starting from planting until harvesting.
\end{abstract}

Keywords: farmer, ceremony.

\section{A. Pendahuluan}

Guradog adalah salah satu desa di Kecamatan Curug Bitung Kabupaten Lebak. Desa Guradog memiliki luas 1.020,34 hektar. Batas wilayah desa di bagian utara adalah Desa Candi, di bagian timur, Kabupaten Bogor; bagian barat, Kecamatan Sajira dan Kecamatan Cipanas; dan bagian selatan, Kecamatan Cipanas.

Secara administratif, Desa Guradog dipimpin oleh seorang kepala desa. Akan tetapi, secara secara budaya, masyarakat Guradog berada di bawah kepemimpinan ketua adat (olot), dibantu oleh sekretaris adat (ketua baris kolot) dan tiga puluh baris kolot. Namun demikian, kepala desa dan ketua adat melaksanakan tugas seiring dan sejalan.

Ketika penelitian dilakukan, penduduk Desa Guradog berjumlah 3.716 orang, terdiri atas laki-laki 1.877 orang dan perempuan 1.833 orang. Mereka memeluk agama Islam. Dalam bidang pendidikan, mayoritas penduduk (1.215 orang) tidak tamat SD. Sebagian dari mereka bermatapencaharian sebagai petani, karena memang sebagian besar lahan desa digunakan sebagai sawah seluas 213 hektar, terdiri atas sawah irigasi setengah teknis seluas 24 hektar dan sawah tadah hujan seluas 189 hektar.

Sebagai masyarakat adat, penduduk Desa kuat memegang tradisi warisan leluhur. Oleh karena itu, tidak heran bila 
banyak upacara tradisional yang berlangsung dalam kehidupan mereka, di antaranya adalah upacara pertanian.

Upacara tradisional sebagai pranata sosial penuh dengan simbol yang berfungsi sebagai media untuk berkomunikasi sesama manusia. Juga, menjadi media penghubung antara dunia nyata dengan dunia gaib. Menurut Budhisantoso (1992:7) upacara tradisional adalah tingkah laku resmi yang dibakukan untuk peristiwa-peristiwa yang tidak ditujukan pada kegiatan teknis sehari-hari, akan tetapi mempunyai kaitan dengan kepercayaan akan adanya kekuatan di luar kemampuan manusia. Berbagai upacara dikembangkan dengan maksud untuk menyampaikan gagasan dan pengalaman pendahulunya, untuk mengukuhkan pendapat, norma-norma, dan agama dengan lambang-lambang.

Menurut Budhisantoso (1992:8), upacara pada hakikatnya terbagi dalam dua kategori yaitu upacara lintasan hidup dan meruwat. Upacara meruwat dilakukan untuk menertibkan kembali keadaan yang dirasa terganggu dengan menghilangkan penyebabnya atau memberikan "imbalan" pada leluhur yang dianggap telah dilupakan orang. Untuk itu upacara yang sering dilakukan adalah upacara tolak bala yang dilakukan untuk membina kesejahteraan perorangan dan masyarakat (upacara seusai panen) dan upacara yang bersifat penyembuhan.

Di dalam upacara tersirat adanya perhitungan tentang hari baik dan buruk termasuk dalam hal bertani. Perhitungan itu menyangkut tentang kapan pekerjaan bertani itu sebaiknya dilakukan, sesaji yang harus disediakan, dan doa atau mantra yang digunakan. Kepercayaan terhadap perhitungan itu dimaksudkan untuk menciptakan hubungan yang harmonis antara manusia, alam, dan roh gaib. Kepercayaan lain adalah bahwa tumbuhan, hewan, benda, serta makhluk halus tertentu memiliki kekuatan gaib yang dapat dimanfaatkan oleh manusia. Dalam hal bertani, kepercayaan itu menjadikan tanaman subur, mencegah/ mengobati hama, dan penolak bala.

Berbagai upacara di Kampung Guradog menarik untuk diteliti, karena seiring berjalannya waktu, tidak mustahil upacara-upacara itu akan terlindas oleh jaman.

Tipe penelitian ini deskriptif dengan metode kualitatif. Langkah-langkah penelitiannya adalah menentukan topik, studi pustaka, mengidentifikasi masalah, menyusun proposal dan instrumen penelitian, penelitian lapangan dengan observasi dan wawancara, penulisan hasil penelitian.

Wilayah penelitian dibatasi di Kampung Guradog. Dari setiap upacara dideskripsikan tentang nama upacara, waktu dan tempat penyelenggaraan, teknis penyelenggaraan, perlengkapan, jalannya upacara, pantangan, dan makna dalam simbol upacara. Dikaji pula faktor pendorongnya, faktor yang berubah, dan fungsinya. Perubahan dilihat dari empat komponen pokok upacara yang dikemukakan Koentjaraningrat yaitu: pemimpin upacara, waktu dan tempat penyelenggaraan, dan perlengkapan upacara. Kajian fungsi upacara mengacu pada pendapat Budhi Santoso (1997/1998:101) yaitu: norma sosial, pengendali sosial, media sosial, dan pengelompokan sosial.

Dalam menganalisa fungsi upacara digunakan teori struktur dari Redclife Brown. Menurut Brown, berbagai aspek perilaku sosial seperti melakukan upacara tradisional justru timbul untuk mempertahankan struktur masyarakat. Struktur sosial merupakan total dari jaringan hubungan antara individu dengan individu dalam masyarakat sebagai hubungan diadik yaitu antara pihak kesatu dan kedua. Selain itu juga 
diferensial antara satu pihak dengan beberapa pihak yang berbeda. Bentuk dari struktur sosial adalah tetap. Kalaupun berubah berjalan lambat. Adapun realitas sosial atau wujud struktur sosial yaitu person-person, kelompok-kelompok yang ada di dalamnya yang selalu berubah dan berganti (Koentjaraningrat, 1992/1993: 4).

Sebagai teori penunjangnya adalah teori fungsional dari B. Malinowski. Menurutnya bahwa berpuluh-puluh pranata yang dihadapi oleh seseorang dalam kehidupannya pada masyarakat nyata, sebaliknya ditanggapi dengan menggunakan suatu kerangka pranata yang berdasarkan prinsip integrasi bagi masyarakat (Koentjaraningrat, 1992/1993: 4 $-5)$.

\section{B. Hasil dan Bahasan}

Beberapa upacara pertanian yang dilakukan oleh masyarakat Guradog di antaranya upacara pertanian, Upacara Mapag Pare Gede, Upacara Selamatan Membasmi Hama, upacara seren taun, Upacara Ngoyos, dan Upacara Rengkong.

\section{Upacara Selamatan Tanam Padi}

Setiap saat menjelang masyarakat tani akan bertanam padi, mereka selalu melaksanakan upacara. Masyarakat pendukungnya menyebutnya dengan selamatan oleh karena tujuannya tidak lain untuk keselamatan dalam bertanam padi.

Waktunya pada saat memasuki musim penghujan, pelaksanaannya sore hari. Pelaksanaan upacara sederhana, tempatnya di rumah ketua baris kolot. Mereka yang terlibat adalah jajaran adat yang meliputi olot, ketua baris kolot, dan ketiga puluh baris kolot, termasuk para istrinya. Sedangkan di luar kelompok adat adalah masyarakat tani yang ikut menanam di pagi hari.
Persiapan dimulai seminggu sebelum hari pelaksanaan. Acaranya adalah musyawarah untuk menentukan hari awal menanam padi di sawah adat yang luasnya 1.5 ha. Ada kepercayaan bahwa hari baik awal bertanam di sawah adat adalah Kamis dan Sabtu. Oleh karenanya mereka pantang bertanam di luar kedua hari itu. Adapun hari awal bertanam di sawah masing-masing diserahkan kepada petani yang bersangkutan. Manakala sudah ada kesepakatan, ketua baris kolot dibarengi tiga puluh baris kolot menghadap olot untuk meminta persetujuan. Setelah itu hari pelaksanaan diumumkan kepada masyarakat. Selanjutnya dua hari sebelum hari pelaksanaan, pembantu ketua baris kolot menggalang dana dari masyarakat untuk biaya selamatan. Besarnya sukarela, pada umumnya berkisar Rp 1000,-. Kalau terjadi kekurangan dana, jajaran adat yang menanggulangi.

Pagi di hari pelaksanaan upacara, kepala keluarga mengirimkan satu orang anggota keluarganya, boleh laki-laki boleh perempuan. Kalau laki-laki, mereka harus bisa mencangkul, sedangkan kalau perempuan harus bisa tandur (menanam benih padi). Istri baris kolot membantu kegiatan memasak di rumah ketua baris kolot, sedangkan istri ketua baris kolot membuat sesaji.

Secara garis besar ada tiga jenis kelengkapan, yaitu: 1). sesaji: kopi pahit dan manis, teh pahit dan manis, air putih, susu, sirih, kemenyan, cerutu, bakakak hayam, dan nasi liwet. Terkecuali kemenyan, sesaji menggambarkan minuman/makanan yang dikonsumsi leluhur pada jamannya. Beberapa kelengkapan merupakan simbol dari nilai-nilai yang mereka anut. Kopi dan teh pahit dan manis menggambarkan bahwa hidup penuh dengan ketidakpastian. Ada senang, ada susah. 
Dipesankan leluhur bahwa manakala hidup sedang senang, panen melimpah, jangan digunakan untuk foya-foya. Bakakak hayam melambangkan kepasrahan. Diartikan bahwa kalau manusia sudah berusaha maksimal tapi belum mendapatkan apa yang diinginkan, harus bisa pasrah. Nasi liwet, melambangkan kesatuan dari keberagaman. Diartikan bahwa warga Guradog, asli atau pendatang, yang mampu secara ekonomi atau tidak, yang memiliki jabatan di pemerintahan/di jajaran adat ataupun tidak, semuanya harus mau menyatu. Sedangkan kemenyan digunakan sebagai media penghubung antara masyarakat pendukung upacara dengan para leluhur. Asap kemenyan dipercaya dapat menyampaikan maksud pelaksanaan upacara kepada leluhurnya. 2). Kelengkapan makan bersama: nasi putih, ikan, orek, dan semur ayam, dan atau menu lainnya yang biasa dikonsumsi warga Guradog. 3). Kelengkapan busana: baju koko atau kampret, sarung, dan iket (ikat kepala). Warna busana bebas, dikenakan oleh ketua baris kolot dan ketiga puluh baris kolot. Baju koko dan sarung menggambarkan bahwa mereka adalah insan muslim, sedangkan baju kampret menggambarkan bahwa mereka adalah masyarakat tani.

Upacara terdiri atas dua tahapan yaitu tandur dan selamatan. Acara selamatan adalah doa yang dipimpin oleh kyai yang intinya memohon keselamatan dalam bertani. Acara diakhiri dengan makan bersama.

\section{Upacara Mapag Pare Gede}

Mapag pare gede dilakukan pada saat padi mulai berbuah. Upacara ini bertempat di rumah olot. Tahapan persiapannya adalah: 1). juru seuneu melaporkan pada olot manakala padi di sawah adat mulai berbuah. 2). olot memerintahkan ketua baris kolot untuk bermusyawarah dengan ketigapuluh baris kolot tentang waktu pelaksaaan upacara. 3). tiga puluh baris kolot memberitahukan kepada penduduk tentang pelaksanaan upacara sekaligus meminta sumbangan berupa uang atau beras.

Pada hari pelaksanaan, upacara diikuti oleh olot, ketua baris kolot, tiga puluh baris kolot, dan beberapa penduduk yang dituakan. Acaranya berupa doa bersama sambil membuat "ramuan" anti hama berupa air putih, makan bersama, lalu peserta upacara pulang dengan membawa "ramuan" sambil memberitahukan kepada yang lain bahwa "ramuan" telah siap. Masingmasing penduduk lalu mengambil "ramuan" untuk dikocorkan di kokocoran.

\section{Upacara Selamatan Membasmi Hama}

Masyarakat menyebut upacara ini dengan selamatan membasmi hama. Tujuannya tidak lain untuk keselamatan padi dalam arti disembuhkan dan dijauhkan dari "penyakit" yang menyerangnya. Upacara ini hanya berlangsung sewaktu-waktu manakala padi di sawah adat terserang hama. Itupun kalau ada kesepakatan dari ketiga puluh baris kolot bahwa padi yang terserang hama bukan hanya diobati dengan obat pembasmi hama, melainkan harus diberi "syarat" melalui acara selamatan.

Tempat yang digunakan adalah rumah ketua baris kolot yaitu untuk kegiatan memasak, tempat pembuatan sesaji, acara selamatan, dan pengambilan sesaji. Sawah adat dan sawah milik masing-masing petani adalah tempat disemprotkannya obat pembasmi hama dan "syarat".

Pelaku upacara adalah jajaran adat dan masyarakat tani. Tugasnya, olot menyaksikan acara selamatan, ketua baris kolot memimpin acara selamatan, 
ketigapuluh baris kolot sebagai peserta selamatan, dan para istri ketigapuluh baris kolot membuat sesaji dan masakan.

Teknis penyelenggaraannya, pengurus sawah adat dan tiga puluh baris kolot bermusyawarah dengan ketua baris kolot untuk mencari kesepakatan tentang obat yang akan digunakan untuk membasmi hama. Bilamana cukup dengan obat maka tidak perlu dilakukan selamatan. Bilamana harus memakai "syarat" maka harus dilakukan selamatan.

Upacara ini sifatnya insidental, oleh karenanya bila akan diselenggarakan selamatan, baru dilakukan penggalangan dana oleh ketua baris kolot. Begitu dana terkumpul, keesokan harinya bisa dilaksanakan selamatan.

Pagi di hari pelaksanaan, para istri baris kolot berkumpul di rumah ketua baris kolot untuk membantu istrinya membuat sesaji berupa rujak kalapa dan bubur merah yang ditempatkan dalam baskom. Usai itu, mereka ke rumah olot untuk membantu istrinya mempersiapkan kelengkapan selamatan berupa: nasi, orek, ikan, atau menu lainnya yang sehari-hari dikonsumsi masyarakat Guradog.

Upacara dilaksanakan di rumah ketua baris kolot, diikuti ketiga puluh baris kolot. Tahapannya adalah doa, makan bersama, dan pengambilan ubar oleh masyarakat tani untuk digunakan di sawah masing-masing. Cara penggunaannya, rujak kalapa diciprat-cipratkan ke sawah, sedangkan bubur merah diruang (ditanam di tanah).

\section{Upacara Seren Taun}

Tujuan upacara tidak lain sebagai tasyakuran panen. Pelaksanaannya seusai panen, hari dan bulannya bergantung pemberitahuan ketua baris kolot Kampung Citorek. Tempat upacara adalah rumah olot dan makam leluhur. Rumah olot digunakan sebagai tempat berkumpul peserta upacara, tempat pemberangkatan menuju makam leluhur, dan tempat acara selamatan. Makam leluhur tempat tahlil dan zikir. Beberapa tempat lain yang digunakan dalam kaitannya dengan pelaksanaan upacara adalah rumah kepala desa dan ketua baris kolot yaitu untuk menginap tamu. Lapangan digunakan untuk panggung hiburan. Rumah olot juga digunakan untuk menginap tamu, selain untuk tempat pertemuan para tamu yang berlangsung pada malam menjelang dilaksanakan upacara seren taun.

Secara teknis, beberapa tahapan persiapannya adalah: 1). ketua baris kolot dari Citorek menghadap ketua baris kolot Guradog. Kedatangannya untuk memberitahukan mengenai hari dan bulan pelaksanaan seren taun. 2). ketua baris kolot Guradog melaporkan kabar dari Citorek tadi kepada olot. 3). setelah ada laporan, seminggu sebelum hari pelaksanaan, ketua baris kolot mengumpulkan tiga puluh baris kolot untuk bermusyawarah mengenai dana dan kelengkapan yang dibutuhkan dalam upacara. 4). petugas yang ditunjuk menggalang dana dari seluruh masyarakat. 5). setelah dana terkumpul, istri wakil olot membeli berbagai keperluan untuk upacara.

Sehari sebelum hari pelaksanaan, berdatanganlah tamu dari berbagai kalangan. Mereka bermalam hingga esok pelaksanaan seren taun usai. Tempat inap mereka dibagi dalam beberapa tempat. Pengaturannya disesuaikan dengan kepentingan atau kesesuaian tugas dan jabatan. Rumah olot diinapi ketua baris kolot dari Citorek dan yang setara jabatannya dengan mereka. Rumah kepala desa diinapi kepala desa dari Citorek, camat, polisi, dan yang setara jabatannya dengan mereka. Rumah ketua baris kolot diinapi baris kolot dari 
Citorek. Kedatangan para tamu dari Citorek tersebut dengan berpakaian koko, bersarung, dan mengenakan iket. Mereka datang sambil membawa oleh-oleh berupa beras, dodol, opak, uli, dan sebagainya yang merupakan hasil bumi mereka selama setahun ke belakang.

Bahan-bahan yang harus dimasak dibagikan ke rumah yang diinapi para tamu. Setiap tamu yang menginap di suatu rumah akan disuguhi makan di rumah tersebut. Kegiatan memasak dilakukan sehari sebelum pelaksanaan upacara dan dilakukan oleh para istri baris kolot. Meskipun demikian kegiatan tersebut tidak tertutup untuk ibu-ibu yang lain. Istri baris kolot tidak memasak di satu tempat, melainkan dibagi ke tempat yang diinapi tamu. Jumlah istri baris kolot yang ditempatkan di satu tempat disesuaikan dengan banyaknya tamu yang menginap di suatu tempat.

Malam hari menjelang pelaksanaan upacara, ketua baris kolot, baris kolot, beserta tamu-tamunya berkumpul di rumah olot untuk bertukar pikiran dengan tamu-tamu yang menginap di rumah olot. Mereka membicarakan hasil panennya masing-masing, juga tentang hama, musim, dan hal-hal lain yang ada kaitannya dengan masalah pertanian. Suguhan acara itu minum dan kue-kue.

Secara garis besar ada dua jenis kelengkapan dalam upacara seren taun yaitu: 1). kelengkapan hasil bumi, di antaranya: dodol, opak, uli, dan beras. Hasil bumi tersebut merupakan hasil bumi dari Guradog yang dihasilkan setahun kebelakang dan diperuntukkan oleh-oleh warga Citorek. 2). Kelengkapan selamatan, di antaranya: nasi putih, orek, ikan, dan semur ayam/semur daging. Jenis kelengkapan selamatan tersebut merupakan gambaran menu makanan sehari-hari masyarakat Guradog.
Jalannya upacara seren taun
sebagai berikut: 1 ). pada hari pelaksanaan, sekitar pukul 08.00 WIB., serentak para tamu dan warga yang akan menjadi peserta upacara,berkumpul di rumah olot. 2). Setelah peserta upacara berkumpul, dengan berjalan kaki mereka bersama-sama menziarahi makam leluhur pendiri desa. 3). Setiba di makam, semua peserta duduk dengan beralas tikar lalu bertahlil dan berzikir dengan dipimpin oleh kyai. Acara tersebut berlangsung lebih kurang dua jam. Usai acara ziarah, mereka bersama-sama menuju rumah olot untuk mengikuti acara selamatan. 4). Acara selamatan, berisi doa dan makan bersama.

Sementara peserta upacara mengikuti selamatan, para pemuda menyelenggarakan panggung hiburan. Panggung hiburan tersebut diperuntukkan warga dan para tamu. Acaranya berupa pertunjukan kesenian di antaranya pencak silat, topeng, dan organ tunggal.

Dalam upacara ini, tamu dari Citorek pulang sekitar pukul 14.00 WIB. Mereka pulang dengan membawa oleholeh berupa hasil bumi dari Guradog.

\section{Upacara Ngoyos}

Tujuan upacara ngoyos tidak lain untuk membersihkan rerumputan yang tumbuh di sekitar tanaman padi. Pelaksanaannya sebulan setelah padi ditanam dan hari pelaksanaannya bergantung kesiapan. Upacara ngoyos hanya dilakukan di sawah adat.

Pelaksanaan upacara ngoyos diawali dengan beberapa persiapan berikut: 1). Pengumuman kepada warga mengenai rencana akan dilaksanakannya ngoyos. 2). Sehari sebelum hari pelaksanaan, petugas khusus dari jajaran baris kolot mengambil beras dari leuit adat. Beras tersebut merupakan hasil dari sawah adat dan digunakan untuk keperluan makan bersama. Bukan saja 
untuk upacara ngoyos, melainkan juga untuk upacara-upacara pertanian yang lain. 3). Pada hari yang sama, istri baris kolot membeli bahan lauk pauk untuk keperluan makan bersama esok harinya. Bahan-bahan tersebut dimasak oleh para istri baris kolot pada keesokan paginya tepat pada hari pelaksanaan upacara.

Jalannya upacara ngoyos sebagai berikut: 1). Pada pagi hari, ketua baris kolot, tiga puluh baris kolot, dan warga (hanya bapak-bapak), berkumpul di sawah adat. 2). Orang yang datang ke sawah adat tersebut dihitung jumlahnya. 3). Setelah diketahui jumlah orangnya, dengan dipimpin ketua baris kolot atau wakilnya, peserta ngoyos ngored tanah dan mencabuti rerumputan. 4). Seusai ngored dan mencabuti rerumputan, acara diakhiri dengan makan bersama di saung.

\section{Upacara Rengkong}

Upacara rengkong dilaksanakan sebagai perwujudan pemuliaan para petani terhadap padi yang menjadi makanan pokok mereka. Penyelenggaraannya pada waktu ngunjal sebelum seren taun. Adapun waktunya hari Jumat atau Minggu.

Upacara rengkong berlangsung mulai dari sawah adat hingga ke leuit adat. Teknis penyelenggaraannya sebagai berikut: 1). tiga hari sebelum hari pelaksanaan, dilakukan musyawarah antara ketua baris kolot dengan tiga puluh baris kolot. Musyawarah tersebut untuk menentukan hari pelaksanaan upacara rengkong, tempatnya di rumah ketua baris kolot. 2). Setelah ada kepastian hari pelaksanaan upacara, lalu diumumkan kepada warga. 3). Mempersiapkan kelengkapan upacara yang secara garis besar berupa: 1). kelengkapan alat: rengkongi (alat untuk membawa padi). 2). Kelengkapan arakarakan di antaranya: petasan, bedil, peralatan kesenian angklung, peralatan kesenian gendang. 3). Kelengkapan makan bersama: nasi putih, ikan, orek, semur. Kelengkapan makan bersama tersebut merupakan menu makanan sehari-hari masyarakat Guradog.

Tahapan upacara rengkong sebagai berikut: 1). pagi pada hari pelaksanaan, ketua baris kolot, tiga puluh baris kolot, beserta masyarakat berkumpul di sawah adat. 2). Petugas khusus menempatkan padi ke dalam lima buah rengkong. 3). Setelah padi siap di dalam rengkong, peserta upacara membentuk arak-arakan Arak-arakan terdiri atas kelompok kesenian gendang, kelompok baris kolot, kelompok pembawa rengkong yang didampingi pemain angklung, dan kelompok warga masyarakat. 4). Dipimpin ketua baris kolot, arak-arakan berarak menuju leuit adat. Pada saat arakarakan berjalan, terdengar sorak-sorai dari kelompok pembawa rengkong dan suara-suara yang menyerupai gangsing yang berasal dari rengkong. Ada pula suara petasan, bedil dan sebagainya. 5). Setiba di leuit adat, tiga orang baris kolot memasukkan padi ke leuit adat dengan disaksikan ketua baris kolot. 6). Usai acara penyimpanan padi, dilanjutkan dengan doa yang dipimpin ketua baris kolot. 7). Acara diakhiri dengan makan bersama.

\section{Penutup}

Padi sampai pada dekade sekarang masih merupakan makanan pokok bagi sebagian besar masyarakat Indonesia. Demikian besar peran padi dalam kehidupan masyarakat, namun demikian tidak lalu padi harus menjadi objek eksploitasi. Dengan kata lain padi bukan sekadar satu jenis tanaman yang ditanam, tumbuh, dan kemudian menghasilkan beras untuk memenuhi kebutuhan pokok masyarakat Indonesia. Budaya Indonesia tidak melihat padi hanya sebagai bahan pangan pokok. Cara melihat padi lebih 
pada hakikat bagaimana sejenis tumbuhan demikian berarti dalam kehidupan manusia. Lebih jauh bahkan dapat menyejahterakan umat manusia. Oleh karenanya tidak heran kalau dalam budaya masyarakat Indonesia padi begitu sangat dimuliakan.

Pemuliaan terhadap padi dipesankan oleh para leluhur bangsa melalui berbagai cara. Melalui isyarat, peringatan, dan anjuran yang di dalamnya memberikan pesan kearifan yang sangat berguna bagi kehidupan masyarakat. Isyarat, peringatan, dan anjuran tersebut di antaranya diwujudkan dalam berbagai upacara yang penuh dengan simbol. Simbol tersebut tentu saja didasarkan atas nilai-nilai etis dan pandangan hidup yang berlaku dalam masyarakat yang bersangkutan. Karena kepentingannya itulah upacara dilakukan secara berulang. Tujuannya, untuk mengingatkan dan menjamin kepatuhan warga terhadap pranata sosial yang sudah berlangsung. Dapat juga dikatakan bahwa berbagai upacara yang berlangsung itu merupakan tradisi penghargaan terhadap padi sebagai bagian dari sistem religi/kepercayaan masyarakatnya.

Upacara yang berlangsung itu berwujud suatu aktivitas dalam rangka berbakti kepada Tuhan, leluhur (pendiri desa dan sebagainya), dan dewa-dewa. Dalam hal kaitannya dengan pertanian adalah dewi padi (Dewi Sri). Upacara tersebut terdiri atas serangkaian tindakan seperti di antaranya bersaji, berkurban, berdoa, dan makan bersama.

Ada tiga unsur yang mendorong dilaksanakannya upacara pertanian di Guradog. Ketiga unsur tersebut adalah: 1). berkaitan dengan kepentingan agama. Bahwasanya upacara pertanian yang dilakukan bertujuan untuk memohonkan keselamatan (dalam bertani) kepada Tuhan Yang Maha Esa. Selain itu juga sebagai ungkapan rasa syukur para petani kepada Tuhan Yang Maha Esa atas segala rahmat dan rizki yang dilimpahkan kepada mereka. Rahmat dan rizki itu dalam bentuk keselamatan dalam kegiatan bertani dan dalam bentuk hasil panen. 2). berkaitan dengan kepentingan adat. Bahwasanya upacara pertanian yang masih terus berlangsung merupakan tradisi penghormatan pada warisan leluhur yang secara tidak langsung diakui memberi jaminan (sugesti) keberhasilan dalam pekerjaan bertani. Selain itu, upacara pertanian yang sudah mentradisi akan menguatkan ingatan warga tentang aturan-aturan yang berlaku di lingkungan masyarakatnya. 3). berkaitan dengan religi/kepercayaan masyarakat. Bahwasanya mereka tidak bisa tidak memercayai adanya kekuatan supranatural. Secara psikologis mereka tersugesti bahwa dengan menyelenggarakan upacara maka semuanya menjadi aman. Adanya perasaan seperti itu membuat orang takut/khawatir/ragu kalau tidak melaksanakan upacara. Hal ini sependapat dengan yang dikemukakan oleh Budhisantoso, bahwa semua upacara pertanian itu pada dasarnya mempunyai kaitan dengan religi/kepercayaan masyarakatnya. Apabila mereka tidak melaksanakan upacara, ada kekhawatiran kalau-kalau terjadi sesuatu yang tidak diinginkan. Dalam pelaksanaannya, ketiga kepentingan tersebut tidak berdiri secara terpisah melainkan berjalan bersama-sama.

Ditilik dari tujuannya, upacara pertanian yang berlangsung di Guradog dikatagorikan ke dalam upacara meruwat yang dilakukan untuk menertibkan kembali keadaan yang dirasa terganggu. Caranya, dengan menghilangkan penyebabnya atau memberi imbalan (sesaji) pada leluhur yang telah terlupakan. Katagori upacara meruwat yang banyak dilakukan masyarakat Guradog adalah upacara tolak bala yang dilakukan untuk 
membina kesejahteraan perorangan dan masyarakat. Tentu saja dengan harapan agar para leluhur memberi perlindungan pada keturunannya. Termasuk perlindungan dalam pekerjaan bertani. Maksudnya adalah agar pada saat menanam padi diberi kelancaran dan kemudahan. Tidak terjadi sesuatu hal yang tidak diinginkan. Selain itu juga berharap agar padi yang ditanam tidak terkena hama dan kelak panennya berhasil dengan baik. Di samping permohonan di atas, ada pula ungkapan rasa terima kasih kepada Tuhan Yang Maha Esa dan Dewi Sri yang dianggap sebagai "ibu padi", atas rahmat yang dilimpahkan kepada mereka. Rahmat tersebut berupa keberhasilan dalam panen.

Ditilik dari keempat komponen pokok upacara yang dikemukakan Koentjaraningrat maka dapatlah dikatakan bahwa seluruh upacara pertanian yang masih dilakukan tidak mengalami perubahan yang berarti. Dengan kata lain, perubahan yang terjadi bukan pada hal yang prinsipil melainkan lebih menunjukkan pada hal yang di luar prinsip. Perubahan oleh karena situasi dan kreativitas semata. Perubahan yang terjadi adalah perubahan nilai-nilai yang bersifat instrumental, bukan nilai hakiki. Gambaran dari keempat komponen pokok tersebut yaitu: 1). pemimpin upacara, tidak menunjukkan terjadi adanya perubahan. Pemimpin upacara hingga kini merupakan keturunan dari pemimpin sebelumnya dan mereka harus menguasai adat istiadat dalam bertani. 2). Waktu penyeleggaraan, ketentuan atau patokannya tidak mengalami perubahan. Pelaksanaan upacara ada di bulan musim penghujan atau manakala padi sedang terserang hama. Waktunya berdasarkan musyawarah antarpemangku adat. 3).Tempat penyelenggaraan upacara, tidak terjadi perubahan. Tempat penyelenggaraan adalah tempat-tempat yang memiliki sejarah dengan kegiatan bertani. Termasuk juga tempat tinggal para pemangku adat. Dengan tidak berubahnya tempat upacara kadang memunculkan sifat keramat pada tempat itu. 4). Perlengkapan upacara, berbeda dengan ketiga komponen di atas, dalam hal perlengkapan upacara tampak terjadi perubahan. Perubahan itu terlihat dalam jumlah, jenis, dan wadahnya. Oleh karena jenisnya bertambah otomatis jumlahnyapun menjadi bertambah. Jenis yang bertambah dalam hal minuman. Ada jenis minuman lain selain kopi manis, kopi pahit, dan teh manis ataupun teh pahit. Seperti susu misalnya. Dengan demikian ada kecenderungan bahwa kelengkapan sesaji menyesuaikan dengan apa yang ada pada saat sekarang. Sedangkan wadahnya yang dahulu terbuat dari bahan yang sederhana (tanah liat kemudian seng) kalau dilihat dari kaca mata kekinian, saat ini sudah terbuat dari bahan plastik, melamin, dan sebagainya. Bahan-bahan wadahnya sebagaimana bahan-bahan perlengkapan rumah tangga yang sekarang ada. Bukan sekadar bahannya, keindahanyapun menjadi perhatian. Wadah-wadah yang digunakan ada yang dihias sedemikian rupa.

Dengan bergulirnya waktu, oleh karena berbagai sebab, bisa jadi berbagai upacara yang kini masih hidup itu akan punah satu demi satu. Selama ini kalau upacara pertanian di Guradog itu masih terus berlangsung lebih disebabkan oleh adanya tiga faktor. Secara garis besar ada tiga faktor yang dapat mempertahankan keberlangsungan upacara pertanian di Guradog. Faktor-faktor yang dimaksud adalah: 1). Peran para pemangku adat seperti olot, ketua baris kolot, dan ketigapuluh baris kolot. Mereka bukan saja menguasai pengetahuan adat-istiadat pertanian di Guradog melainkan 
sekaligus patuh pada amanat leluhur. Mereka konsisten melaksanakan upacara dan oleh karenanya upacara-upacara pertanian itu hingga kini masih berlangsung. Kepatuhan warga pada para pemangku adat didasari kenyataan bahwa secara tidak langsung melalui merekalah kehidupan bertani mereka berhasil. Dengan kata lain, warga masyarakat selalu diingatkan untuk melaksanakan upacara dengan tuntunan mereka. Dengan melaksanakan upacara, masyarakat tani merasa aman dalam pekerjaan pertaniannya. Oleh karena perannya itulah tidak heran kalau pada masyarakat tradisional peranan pemimpin informal seperti para pemangku adat sangatlah kuat. 2). Adanya mitos yang berkaitan dengan kemurkaan alam. Hal ini berkaitan dengan kepercayaan akan kekuatan supranatural. Sehubungan dengan itu mereka perlu memelihara keseimbangan tatanan kosmis dengan menyelenggarakan upacara. Melalui upacara itulah mereka bersaji. Sesaji ini secara tidak langsung merupakan simbol dari harapan-harapan mereka. Menunjukkan bahwa simbol merupakan sarana untuk menitipkan pesan. Dengan melakukan upacara yang di dalamnya ada aktivitas bersaji maka diharapkan bisa menghubungkan antara manusia dengan leluhur, dan roh halus. Sesaji ini bisa dianggap sebagai "imbalan" terhadap leluhur yang mungkin saja terlupakan. Asap kemenyan yang mengepul dipercaya bisa menyampaikan pesan kepada leluhur. 3). Upacara-upacara itu masih berfungsi bagi masyarakat pendukungnya.

Dari ketiga faktor tersebut, tampaknya faktor ketigalah yang paling menguatkan keberlangsungan upacara. Kalau saja upacara pertanian yang masih berlangsung itu tidak lagi dirasakan fungsinya, apapun alasannya, tentulah upacara itu tidak lagi dilaksanakan.
Ditilik dari fungsinya, seperti yang dikemukakan oleh Budhi Santoso, setiap upacara tradisional yang terdapat pada masyarakat pendukungnya dapat mengandung empat fungsi. Demikian pula dengan upacara pertanian yang berlangsung di Guradog. Fungsi-fungsi tersebut adalah: 1). sebagai norma sosial. Dari keseluruhan upacara pertanian yang ada, nyaris semuanya menggunakan sesaji. Sesaji tersebut mengandung simbol yang bermakna tertentu. Makna tersebut tentang nilai-nilai yang harus dipedomani dalam kehidupan sehari-hari. Di antaranya tentang penghargaan kepada para pendahulu dan keteguhan memegang amanat yang diwujudkan. dengan selalu melaksanakan upacara. Tentang kehidupan yang sifatnya tidak pasti dan oleh karenanya setiap orang tidak boleh terlena dengan kesenangan yang sedang dirasakan. 2). Sebagai pengendali sosial. Norma-norma sosial yang terkandung dalam upacara merupakan refleksi nilai-nilai kehidupan yang berlaku pada masyarakat pendukungnya. Dengan disosialisasikannya nilai-nilai yang berlaku melalui upacara, secara tidak langsung akan mengingatkan masyarakatnya tentang pola kehidupan, tata kelakuan, dan lain sebagainya yang berlaku di lingkungan masyarakatnya. "Peringatan", apalagi yang terus dilakukan secara berulang akan mampu mengendalikan kehidupan masyarakatnya pada tatanan kehidupan yang positif. 3). Sebagai media sosial. Bahwasanya upacara pertanian yang berlangsung bukan sekadar seremonial semata melainkan aktivitas yang bersimbol. Simbol ini mengandung makna tentang nilai-nilai kehidupan. Menilik dari kandungannya tersebut dapat dipastikan bahwa orang tua-tua dulu bukan sekadar menciptakan atau melaksanakan upacara untuk seremoni semata. Simbol-simbol dalam upacara tersebut sebagai sarana 
untuk menitipkan pesan. Apa yang terkandung di dalam upacara tersebut untuk diketahui oleh masyarakat luas. Dengan demikian upacara pertanian yang dilakukan oleh para petani khususnya, sesungguhnya merupakan media sosial dari orang tua-tua kepada generasi berikutnya.4). Sebagai pengelompokan sosial. Setiap upacara pertanian yang berlangsung, dilakukan atau diikuti oleh banyak orang. Dari jumlah pesertanya akan membawa pengaruh yang baik untuk terjalinnya interaksi sosial dan terwujudnya kesatuan masyarakat. Selain itu, adanya pekerjaan di dalam pelaksanaan upacara yang harus dikerjakan bersama akan menguatkan rasa gotong royong yang menjadi ciri khas masyarakat pedesaan..

Melihat dari beberapa fungsinya itu, selayaknyalah harus ada upaya untuk melestarikannya. Berdasarkan kebijakan dari Kementrian Kebudayaan dan Pariwisata Deputi Bidang Pelestarian dan Pengembangan Kebudayaan, pelestarian dimaksudkan sebagai upaya perlindungan dari kemusnahan atau kerusakan warisan budaya yang bersifat non fisik (intangible culture) dan yang bersifat fisik (tangible). Pada warisan budaya yang bersifat non-fisik, dapat dikatakan bahwa pelestariannya bersifat dinamis dan bukan statis. Dengan demikian masih dimungkinkan adanya ruang untuk perubahan. Sedangkan pada warisan budaya yang bersifat fisik adalah merupakan suatu upaya agar sesuatu benda tidak berubah, tetap sebagaimana keadaan semula, serta dipertahankan keberadaan dan keabadiannya seperti benda-benda peninggalan purbakala (2004:5).

Setelah ada upaya pelestarian, ditindaklanjuti dengan upaya pengembangan. Pengembangan itu sendiri adalah upaya perluasan dan pendalaman perwujudan budaya. Tentu saja dibarengi peningkatan mutu dengan mempertahankan berbagai sumber dan potensi, tanpa menghilangkan nilai-nilai budaya yang terkandung di dalamnya. Pengembangan itu digunakan untuk kepentingan pendidikan, ekonomi, ilmu pengetahuan dan lain-lain.

Terlepas dari faktor-faktor yang melatarbelakangi dilaksanakannya upacara dan tujuan dari upacaranya itu sendiri maka seiring dengan kebijakan pemerintah yang menempatkan aspek pariwisata berbasis budaya sebagai salah satu sumber devisa negara, tampaknya upacara pertanian yang masih berlangsung di Guradog itu dapat dipertimbangkan untuk dilirik. Meskipun dilihat dari tampilannya, upacara pertanian yang berlangsung itu relatif sederhana, namun demikian keunikannya bisa dijadikan modal sebagai objek wisata budaya. Bagi wisatawan mancanegara (wisman), keunikan budaya tersebut akan menumbuhkan minat dan ketertarikannya dalam berwisata.

\section{DAFTAR PUSTAKA}

Budhisantoso, S. 1992/1993. Upacara Tradisional. Bandung: P3NB, Direktorat Sejarah dan Nilai Tradisional Direktorat Jenderal Kebudayaan.

Djatisunda, Anis. 1992.

Pengalaman Bergaul Dengan Orang Baduy. Bandung: Museum Negeri Jawa Barat "Sri Baduga".

Depdikbud. 1992/1993. Fungsi Upacara Tradisional Pada Masyarakat Pendukungnya Masa Kini. TOR. Direktorat Jarahnitra.

Jawa Barat. Disbudpar. 2007.

Petunjuk Pelaksanaan Inventarisasi Upacara Tradisional. Bandung. 
Martodirdjo, Haryo S. 1996.

Pengertian dan Batasan Serta

Dinamika Kebudayaan. Jakarta:

Direktorat Sejarah dan Nilai-nilai Tradisional.

Moertjipto et al. 1997-1998.

Upacara Tradisional Mohon

Hujan Desa Kepuharjo Cangkringan Sleman Daerah Istimewa Yogyakarta. Yogyakarta: Depdikbud. Dirjen. Kebudayaan Direktorat Jarahnitra. P3NB.

P3NB (TOR) 1992/1993.

Fungsi Upacara Tradisional Pada Masyarakat Pendukungnya Masa Kini. Jakarta: Dirjen. Kebudayaan.

Rajab, Budi.

Metode Penelitian Kebudayaan, makalah dalam Kegiatan Pelatihan Tenaga Peneliti 1995.
Rianto, Hermawan et al. 2001.

Kultur Padi. Jakarta: Museum Nasional.

Sukari. 2004.

Kebijakan Pelestarian dan Pengembangan Kebudayaan.

Kementerian Kebudayaan dan Pariwisata. Deputi Bidang Pelestarian dan Pengembangan Kebudayaan Proyek. Pengembangan Kebijakan Nilai Budaya.

2007.

"Upacara Adat di Lingkungan Masyarakat Tengger", dalam Patrawidya. Volume 8 Nomor 4, Desember. 2007: 803 - 84.

Suryaatmana, Emon et al. 1992/1993.

Paririmbon Sunda (Jawa Barat). Jakarta: Depdikbud. Bagian Proyek Penelitian dan Pengkajian Kebudayaan Nusantara. 